\title{
Molecular Genetics Tools to Understand Foaming and Bulking Filamentous Bacteria in Wastewater Treatment Plants
}

\section{Abd El-Latif Hesham ${ }^{1,2 *}$}

${ }^{1}$ Genetics Department, Faculty of Agriculture, Assiut University, Assiut, 71516, Egypt ${ }^{2}$ Biology Department, Faculty of Science, King Khalid University, Abha, Saudi Arabia

Water is a critical need not only for human survival, but also for all forms of living organisms and for the conservation of the ecosystems on a global scale. Water contamination is now a major problem in the global context as a consequence of industrialization, globalization, population growth, urbanization and warfare combined with increased wealth and more extravagant lifestyles. Therefore wastewater treatment has gained increased importance worldwide due to increasing demand on fresh clean water supplies.

Biological treatment achieved by the activities of micro-organisms (activated sludge), is one of the most important biotechnological processes which is used worldwide to treat municipal and industrial sewage. Activated sludge is a very complicated system, comprised of various populations including heterotrophic bacteria, autotrophic bacteria, fungi and protozoa [1]

It is common knowledge that in all types of wastewater treatment plants, prokaryotic microorganisms dominate and are responsible for the observed conversions. The most frequently found prokaryotes in biological wastewater treatment systems belong to the classes Alpha-, Beta- and Gammaproteobacteria, Bacteroidetes and Actinobacteria [2]. High numbers and activities of some groups of micro-organisms are required to treat wastewater in biological processes. In contrast, some groups of micro-organisms must be absent from the system since their presence and activities cause problems in the treatment of wastewater like activated sludge bulking and foaming [3].

\section{Sludge Bulking and Foaming Problems}

Bulking and foaming are the main biological problems in activated sludge wastewater treatment plants, which is caused by the excessive growth of filamentous bacteria extending outside the flocs, resulting in decreasing the wastewater treatment efficiency and deteriorates the water quality in the effluent.

Actinobacteria of the genus Microthrix Parvicella, is one of the most common filamentous bacteria found in biological wastewater treatment plants, where it is reported to be responsible for the problems of solid-liquid separation in bulking and foaming in activated sludge plants worldwide $[4,5,6,7,8]$. M. parvicella, is a gram-positive, longcoiled filament, thin (diameter of $0.6-0.8 \mu \mathrm{m}$ ), non-branched with hydrophobic cell walls. It is a highly specialist feeder in activated sludge plants by utilizing only long chain fatty acids such as oleic acid, not only under aerobic conditions but also with nitrate (anoxic conditions) present as electron acceptor [9]. These characters enable $M$. parvicella to outcompete other bacteria present in activated sludge [10].

\section{Control Activated Sludge Bulking and Foaming}

Filamentous bulking and foaming can be controlled by specific strategies. These strategies are associated with the filamentous proliferation without though addressing the actual cause of the filamentous growth. Therefore, analyzing and identifying the causative population is essential to control and solve the problems.
Whereas M. parvicella is difficult to cultivate in pure culture $[8,11$ 13]. Due to its rather peculiar nutritional requirements, only a short time is needed to obtain the final result about $M$. parvicella abundance to predict the development in plant which enable the engineers to control the filamentous troubles, so Tools for in situ identification including molecular techniques such as fluorescence in situ hybridization (FISH), and quantitative real-time PCR (QRT-PCR) are needed.

\section{Fluorescent in Situ Hybridization (FISH)}

FISH technique is one of these recent molecular techniques, that is useful to identify and determine the abundance of respective populations in bacterial community especially those that are hard to grow using ribosomal RNA (rRNA)-targeted oligonucleotide probes, the targeted probe contains a fluorescent molecule and the probes hybridize with complementary $16 \mathrm{~S}$ rRNA structure in the microbial cell. In microbiology the most commonly used target molecule for FISH is 16S rRNA because of its genetic stability, its domain structure with conserved and variable regions, and its high copy number [2]. The FISH procedure consist of the following steps (a) preparing specific probes; (b) microbial cell fixation of the sample; (c) hybridization the specific probes with target sequences; (d) washing to remove unbound probes; (e) visualization of results by confocal laser scanning microscopy; (f) sample analysis. Filamentous bacteria in activated sludge can be identified and in situ quantified using FISH analysis. Several benefits of FISH have been found with respect to conventional microscopic identification: (I) the method requires little knowledge of filaments, (II) is independent of morphological variability, (III) quantification is highly sensitive and accurate and (IV) the FISH samples can be stored for years without loss of signal. Specific 16S rRNA-targeted probes were developed by Erhart et al. [14] for the FISH method, which could successfully highlight and detect generically " $M$. parvicella" filaments in wastewater treatment plants in several countries.

\section{Quantitative Real-time PCR}

Recent applications of molecular techniques based on PCR using 16SrRNA genes to environmental samples have shown the powerful of studying microbial populations in the absence of culturing. In conventional PCR, the amplified product is detected by an end-point

*Corresponding author: Abd El-Latif Hesham, Genetics Department Faculty of Agriculture, Assiut University, Assiut, 71516, Egypt, E-mail: hesham_egypt5@yahoo.com

Received November 27, 2012; Accepted November 29, 2012; Published December 03, 2012

Citation: Hesham AEL (2012) Molecular Genetics Tools to Understand Foaming and Bulking Filamentous Bacteria in Wastewater Treatment Plants. J Microbial Biochem Technol 4: xvii-xviii. doi:10.4172/1948-5948.1000e113

Copyright: ( 2012 Hesham AEL. This is an open-access article distributed under the terms of the Creative Commons Attribution License, which permits unrestricted use, distribution, and reproduction in any medium, provided the original author and source are credited 
Citation: Hesham AEL (2012) Molecular Genetics Tools to Understand Foaming and Bulking Filamentous Bacteria in Wastewater Treatment Plants. J Microbial Biochem Technol 4: xvii-xviii. doi:10.4172/1948-5948.1000e113

analysis, by running DNA on an agarose gel after the reaction has finished. In contrast, Quantitative real-time PCR (QRT-PCR) allows the accumulation of amplified product to be detected and measured as the reaction progresses, that is, in "real time". Real-time detection of PCR products is made possible by including in the reaction a fluorescent molecule that reports an increase in the amount of DNA with a proportional increase in fluorescent signal. QRT-PCR approach is now widely applied in microbial ecology to identify and quantify the abundance of microorganisms within the environment [15-18]. QRTPCR is reported to be highly accurate in quantifying the microbial community from a mixed environment. Several benefits of QRT-PCR as advantage have been found over conventional PCR: (I) Results in less time and data can be evaluated without gel electrophoresis, (II) Identify problems and fix them faster, (III) Allows you to determine the starting template copy number with accuracy and high sensitivity over a wide dynamic range. This technique was also used to identify and quantify filamentous bacteria that causing foaming and bulking problems such as Type $021 \mathrm{~N}$ and $M$. parvicella in sewage treatment plant samples [19-25]

\section{References}

1. Madoni P, Davoli D, Chierici E (1993) Comparative analysis of the activated sludge microfauna in several sewage treatment works. Water Res 27: 14851491.

2. Woese CR (1987) Bacterial evolution. Microbiol Rev 51: 221-271.

3. Coskuner G (2002) A New Molecular Technique for the Identification of Microorganisms in Biological Treatment Plants: Fluorescent In Situ Hybridization. Turk J Biol 26: 57-63.

4. Blackbeard JR, Ekama GA, Marais GVR (1986) A survey of filamentous bulking and foaming in activated sludge plants in South Africa. Water SA 14: 29-34.

5. Eikelboom DH, Andreadakis A, Andreasen K (1998) Survey of filamentous populations in nutrient removal plants in four European countries. Water Sci Technol 37: 281-289.

6. Jenkins D, Richard MG, Daigger GT (2004) Manual on the causes and control of activated sludge bulking, foaming, and other solids separation problems. (3rdedn), IWA Publishing, London.

7. Martins AM, Pagilla K, Heijnen JJ, van Loosdrecht MC (2004) Filamentous bulking sludge--a critical review. Water Res 38: 793-817.

8. Rossetti S, Tomei MC, Nielsen PH, Tandoi V (2005) "Microthrix parvicella", a filamentous bacterium causing bulking and foaming in activated sludge systems: a review of current knowledge. FEMS Microbiol Rev 29: 49-64.

9. Andreasen K, Nielsen PH (2000) Growth of Microthrix parvicella in nutrient removal activated sludge plants: studies of in situ physiology. Water Res 34 1559-1569.

10. Rossetti S, Tomei MC, Levantesi C, Ramadori R, Tandol V (2002) "Microthrix parvicella": a new approach for kinetic and physiological characterization. Water Sci Technol 46: 65-72.

11. Blackall LL, Stratton H, Bradford D, Dot TD, Sjörup C, et al. (1996) "Candidatus Microthrix parvicella", a filamentous bacterium from activated sludge sewage treatment plants. Int J Syst Bacteriol 46: 344-346.

12. Eikelboom DH (1975) Filamentous organisms observed in activated sludge. Water Research 9: 365-388.

13. Tandoi V, Rosseti S, Blackall L, Majone M (1998) Some physiological properties of an Italian isolate of "Microthrixparvicella". Water Sci Tech 37: 1-8.

14. Erhart R, Bradford D, Seviour RJ, Amman RI, Woese CR (1987) Bacterial evolution. Microbiol Rev 51: 221-271.

15. Davenport RJ, Curtis TP (2002) Are filamentous mycolata important in foaming? Water Sci Technol 46: 529-533.

16. Beller HR, Kane SR, Legler TC, Alvarez PJ (2002) A real-time polymerase chain reaction method for monitoring anaerobic, hydrocarbon-degrading bacteria based on a catabolic gene. Environ Sci Technol 36: 3977-3984.

17. Yu Y, Lee C, Kim J, Hwang S (2005) Group-specific primer and probe sets to detect methanogenic communities using quantitative real-time polymerase chain reaction. Biotechnol Bioeng 89: 670-679.

18. An HR, Mainelis G, White LA (2006) Development and calibration of real-time $\mathrm{PCR}$ for quantification of airborne microorganisms in air samples. Atmospheric Environment 40: 7924-7939.

19. Vervaeren H, De Wilde K, Matthys J, Boon N, Raskin L, et al. (2005) Quantification of an Eikelboom type $021 \mathrm{~N}$ bulking event with fluorescence in situ hybridization and real-time PCR. Appl Microbiol Biotechnol 68: 695-704.

20. Kaetzke A, Jentzsch D, Eschrich K (2005) Quantification of Microthrix parvicella in activated sludge bacterial communities by real-time PCR. Lett Appl Microbio 40: 207-211.

21. Kumari SK, Marrengane Z, Bux F (2009) Application of quantitative RT-PCR to determine the distribution of Microthrix parvicella in full-scale activated sludge treatment systems. Appl Microbiol Biotechnol 83: 1135-1141.

22. Bitton G (2005) Wastewater Microbiology. (3rdedn), A John Wiley \& Sons INC., New Jersey.

23. Erhart R, Bradford D, Seviour RJ, Amann R, Blackall LL (1997) Developmen and Use of Fluorescent In Situ Hybridization Probes for the Detection and Identification of "Microthrix parvicella" in Activated Sludge. Syst Appl Microbio 20: 310-318.

24. de los Reyes FL 3rd, Rothauszky D, Raskin L (2002) Microbial community structures in foaming and nonfoaming full-scale wastewater treatment plants. Water Environ Res 74: 437-449.

25. Wagner M, Loy A (2002) Bacterial community composition and function in sewage treatment systems. Curr Opin Biotechnol 13: 218-227. 